\title{
The impact on large fibre function and small fibre function in patients with type 2 diabetes on benfotiamine therapy
}

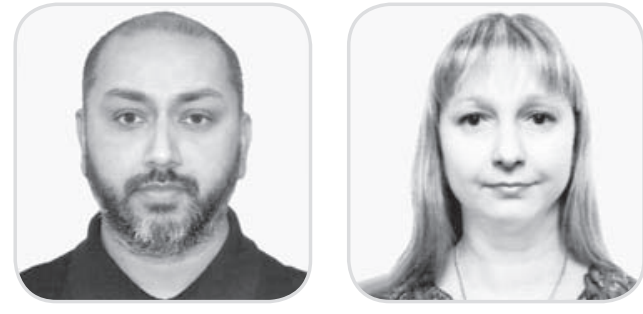

Diabetes mellitus (DM) is the leading cause of neuropathyworldwide. Based on the data from several studies sensorimotor polyneuropathy (diffuse and symmetric neuropathy) will develop within 10 years of the onset of DM in $40 \%$ to $50 \%$ of patients with type 1 and type 2 DM [1, 2]. Patients with DM have higher occurrence rates of premature death, disability, and coexisting conditions compared to healthy individuals. Some of the most common and debilitating complications of diabetes is diabetic foot syndrome which is associated with diabetic peripheral neuropathy (DPN). DPN is closely related to changes in the brain structure, especially a reduction in peripheral grey matter volume, which can lead to walking disabilities [3].

The quality of life of patients with DPN may suffer which in turn leads to high costs of care [4]. Symptoms in patients may vary according to the class of sensory fibres which are involved. The most common early signs are from small fibre involvement and include sharp shooting pain and burning sensation. Pain may be present in the presence of a normal clinical examination and normal nerve conduction studies, which are a measure of large fibre function [5]. The involvement of large fibres may cause numbness, tingling and loss of protective sensation. Diabetic polyneuropathy develops as a result of chronic hyperglycemia and prolonged hyperglycemic status seems to be the most important factor [6]. Other

\section{K. Singh, T. Yuzvenko}

Ukrainian Research and Practical Centre for Endocrine Surgery, Transplantation of Endocrine Organs and Tissues, Health Ministry of Ukraine, Kyiv

potential mechanisms contributing to the development of DPN include oxidative injury, activation of the polyol pathway of glucose metabolism, deposition of advanced glycosylation end products within the nerves, and vascular insufficiency [6].

In patients with type $2 \mathrm{DM}$, target blood glucose levels are associated with a reduced frequency of neuropathy [7]. No other clearly efficacious diseasemodifying treatments are currently available. Multiple treatments are available for the management of neuropathic pain, and detailed evidence-based guidelines on the treatment of painful diabetic neuropathy have been published.

Objective - to study the correlation between the stage of diabetic peripheral polyneuropathy in type 2 diabetic patients and the impact and efficacy of transketolase activator agents as a novel drug for treating.

\section{MATERIALS AND METHODS}

In this study, 190 patients with type 2 DM were screened for DPN in the out-patient and in-patient departments at the Ukrainian Research and Practical Center for forEndocrine Surgery,Transplantation of Endocrine Organs and Tissues. DPN was confirmed in 105 patients displaying both clinical manifestations of neuropathy with a positive Diabetic Neuropathy Symptom (DNS) score and increased vibration 
Results of diabetic neuropathy score in patients with type 2 DM

\begin{tabular}{|c|c|c|c|c|c|c|c|c|}
\hline \multirow{2}{*}{$\begin{array}{l}\text { Group/ } \\
\text { assessment criteria }\end{array}$} & \multicolumn{2}{|c|}{ Group 1} & \multicolumn{2}{|c|}{ Group 2} & \multicolumn{2}{|c|}{ Group 3} & \multicolumn{2}{|c|}{ Group 4} \\
\hline & $M(n=6)$ & $F(n=18)$ & $M(n=14)$ & $F(n=37)$ & $M(n=1)$ & $F(n=4)$ & $\begin{array}{l}M(n= \\
5)\end{array}$ & $F(n=20)$ \\
\hline DNS & $1-3$ & $1-2$ & $2-3$ & $2-4$ & 4 & 4 & 1 & $1-2$ \\
\hline DNS post therapy & $1-2,5$ & $1-1,5$ & $2-3$ & $2-4$ & 4 & $3,5-4$ & 1 & 1 \\
\hline VPT, V & $20-25$ & $17-25$ & $26-35$ & $26-34$ & 39 & $38-41$ & $6-11$ & $6-9$ \\
\hline VPT post therapy, V & $19-22$ & $16-21$ & $24-31$ & $24-28$ & 39 & $38-40$ & $6-11$ & $6-9$ \\
\hline$\%$ reduction in VPT, \% & $5-12$ & $5,88-16$ & $7,7-11,4$ & $7,7-17,6$ & 0 & $0-2,5$ & 0 & 0 \\
\hline
\end{tabular}

perception threshold (VPT) on a bio-tensiometer.All the participants in the study had an average duration of DM (7-12 years) and were assessed using the DNS score, vibration perception threshold, 5.07-10 Gm onofilament test for testing protective sensory loss of the feet, complete blood count,kidney profile tests,liver function tests, thyroid function, glycosylated hemoglobin $(\mathrm{HbA} 1 \mathrm{c})$ were measured in all the subjects. The questionnaire used was the DNS score. The score is based upon the regular occurrence of four different symptoms of distal sensory polyneuropathy, including tingling, burning, numbness and unsteadiness of gait. The score has a range of $0-4$, and a score of $\geq 1$ is considered indicative of DPN. Vibration perception threshold was graded as $0-15$ volts normal, $16-25$ volts as mild sensory loss, 26-35 as moderate sensory loss and > 36 as severe sensory loss. The $10 \mathrm{~g}$ monofilament test was conducted on the 10 sites i.e. dorsal between base digit 1-2; ventral digit 1, 3, 5; metatarsal heads 1, 3, 5; medial and lateral mid foot and heel. A score of $>8(8 / 10)$ sites was considered normal, whereas a score of $<8$ was considered positive for protective sensory loss in the patient.

Based on the above stated criteria patients were divided into 4 groups: 1 - with positive DNS score, positive $10 \mathrm{~g}$ monofilament test score, VPT between $16-25$ volts ( $n=24(22.8 \%), 18$ females and 6 males). 2 - with positive DNS score, positive $10 \mathrm{~g}$ monofilament test score, VPT between $26-35$ volts $(n=51$ (48.5\%), 37 females and 14 males). 3 - with positive DNS score, positive $10 \mathrm{~g}$ monofilament test score and VPT between $35-40$ volts ( $n=5(4.76 \%)$, females 4 and male 1$) .4-$ control group with positive DNS score, negative $10 \mathrm{~g}$ monofilament test score and normal VPT value $(n=25$ (23\%); 20 females and 5 males). The first 3 groups received benfothiamine $300 \mathrm{mg}$ daily for 6 weeks, the control group was benfothiamine naïve. All the groups continued to take their anti-diabetic medication.
After 6 weeks therapy all the four groups were assessed again using the DNS score and VPT.The level of reduction (\%) in vibration perception threshold was calculated with the mathematical formula: \% VPT reduction $=($ VPT0 - VPT1 $) /$ VPT0 $\times 100$, where VPT $0-$ vibration perception threshold before benfothiamine therapy, VPT 1 - vibration perception threshold after 6 weeks of benfothiamine administration. Patients with complaints of neuropathic pain in the feet were not given any gabapentinoid class of drugs during the studyand had not been on such medication at least 4 weeks before therapy.

\section{RESULTS AND DISCUSSION}

The diabetic neuropathy score and vibration perception threshold was assessed in 105 patients (84 females and 21 males) with type 2 DM, before commencement of benfotiamine $300 \mathrm{mg}$ daily and after 6 weeks of therapy.

The results are depicted in table

Results of DNS: differences between group 3 and both group 1 and 2 were significant, but not between group 1 and 2. Patients in group $1(n=24)$, in females $(n=18)$ the DNS varied from $1-2$, and in males $(n=6)$ the DNS varied from $1-3$. After the 6 week period the DNS decreased in both the female and males i.e. $1-1.25$ and $1-2.5$ correspondingly. Patients in group $2(n=51)$ in females $(n=37)$ the DNS varied from $2-4$, and in males $(n=14)$ the DNS varied from $2-3$. After the benfothiamine intake period the second group showed decrease in the DNS score more considerably in the female as compared to the males in the group, females $1-3$ and males $2-2.25$. In group $3(n=5)$ in females $(n=4)$ the DNS was 4 , and in male $(n=1)$ the DNS was 4 . After the 6 week period there was a slight inconclusive decrease in DNS in the female part with the score varying $3-4$, and in the male with no changes in DNS. 
Results of the vibration perception threshold: again as in the case of the DNS here too the difference between group 3 and both group 1 and 2 were significant, but group 1,2 exhibited a similar trendbut with different values. Patients in group $1(n=24)$, in females $(n=18)$ the VPT varied from $17-25$ volts, and in males $(n=6)$ the VPT varied from $20-25$ volts. After the 6 week period the vibration perception threshold decreased in both the female and males i.e. 16-21 volts and $19-22$ volts correspondingly. Patients in group $2(n=51)$ in females $(n=37)$ the VPT varied from $26-34$, and in males $(n=14)$ VPT varied from $26-35$.

After the benfothiamine intake period the second group showed decrease in VPT (7.7-17 \%) in both the male and female patients, as compared to the other groups more significantly, in females VPT decreased and varied from $24-28$ volts, and in males varied from $24-31$ volts. In group $3(n=5)$ in females $(n=4)$ VPT was 4 , and in male $(n=1)$ VPT was 4 . After the 6 week period there was a slight inconclusive decrease in VPT in the female category with VPT decreasing by 2 volts in 2 patients, and in the male with no changes in VPT at all.

As seen in table the average reduction in vibration perception threshold reduced in group 1 with mild sensory loss was by 5 to $16 \%$. In group 2 with moderate sensory loss the reduction was slightly more significant with value of $7.7-17.6 \%$.

In the final stage of ourstudy we shortlisted patients from group 1 and group 2 and group 4, for studying the correlation of benfothiamineintake, its effect on changes in VPT and DNS in patients with mild and moderate DNP and its effect on the expression of genes of the solute carrier family.

Thiamine is absorbed from both small and large intestines by utilizing thiamine transporters- 1 and -2 (THTR-1 and THTR-2). These transporters belong to the family of solute carriers (SLCS) Both these transporters facilitate absorption of thiamine in micromolar to nanomolar range from the intestinal lumen and follow saturation kinetics principles. These transporters are also expressed in other tissues such as pancreas, kidney, and brain [8], which facilitates free thiamine transport into the tissues [9-12]. The results of the gene expression will be presented in the consequent article.

\section{CONCLUSION}

The significance of benfothiamine in clinical practice has been demonstrated in many clinical trials with variable trial structures, patient groups and history of diabetes. In our study we found that patients with mild neuropathy and vibration perception threshold of 16-25 volts showed a reduction in VPT of up to $16 \%$, andthe patients with moderate neuropathy and reduced vibration perception threshold of $26-35$ volts were the ones who benefitted the most from benfothiamine therapy. After 6 weeks of therapy their VPT showed significant reduction upto $17.6 \%$. As the damaging effects of hyperglycaemia are seen in peripheral nerves in the form of DPN. Glycolytic intermediates can flow to the pentose phosphate shunt with the activation of transketolase and the extent of flow depends proportionally to the concentration of substrate presented to transketolase. Benfothiamine activates transketolase and thus helps in the reduction of AGEs formation and associated sugar induced metabolic stress.

Authors' contributions. K. Singh and T. Yuzvenko participated in the conception and design of the study. All authors took part in the collection and analyses of the data. KSingh drafted the initial manuscript and T. Yuzvenko revised the manuscript. All authors read and approved the final manuscript.

Acknowledgments - not applicable.

Competing interests - the authors declare that they have no competing interests.

Ethics approval and consent to participate. This study conformed to the guidelines of the Declaration of Helsinki, and the study procedures were reviewed and approved by the medical research ethics committee Each patient agreed to participate and signed the informed consent form.

Funding. The study was self funded.

\section{REFERENCES}

1. Martin CL, Albers JW, Pop-Busui R et al. Neuropathy and related findings in the diabetes control and complications trial/epidemiology of diabetes interventions and complications study. Diabetes Care. 2014;37:31-38. doi: 10.2337/dc13-2114.

2. Pankiv VI. Influence of methylcobalamin on the vitamin B12 level and manifestation of neuropathy in patients with type 2 diabetes mellitus and metformin-associated vitamin B12 deficiency. Mižnarodnij endokrinologičnij žurnal. 2019;15(4):45-49. doi: 10/22141/22240721.15.4.2019.174818.(in Ukrainian).

3. Koufopoulos G, Pafili K, Papanas N. Correlation between type 2 diabetes mellitus and ankle-brachial index in a geographically specific Greek population without peripheral arterial disease.Mižnarodnijendokrinologičnij 
žurnal. 2019;15(7):9-14. doi10.22141/22240721.15.7.2019.186053

4. Selvarajah D, Wilkinson ID, Maxwell M et al. Magnetic resonance neuroimaging study of brain structural differences in diabetic peripheral neuropathy. Diabetes Care. 2014;37(6):1681-8. doi: 10.2337/dc13-2610.

5. Ebata-Kogure N, Nozawa K, Murakami A et al. Clinical and economic burdens experienced by patients with painful diabetic peripheral neuropathy: An observational study using a Japanese claims database. PLoS One. 2017;12(10):e0187250. doi:1371/journal. pone. 0187250.

6. Khdour MR. Treatment of diabetic peripheral neuropathy: a review. J Pharm Pharmacol.2020.- doi: 10.1111/jphp.13241.

7. Iqbal Z, Azmi S, Yadav R et al. Diabetic Peripheral Neuropathy: Epidemiology, Diagnosis, and Pharmacotherapy. Clin Ther. 2018;40(6):828-849. doi: 10.1016/j.clinthera.2018.04.001.

8. Yang $H$, Sloan $G$, YeY et al. New Perspective in Diabetic Neuropathy: From the Periphery to the Brain, a Call for Early Detection, and Precision Medicine. Front. Endocrinol. (Lausanne). 2020;10:929. doi: 10.3389/ fendo.2019.00929. eCollection 2019.

9. Ortigoza-Escobar JD, Molero-Luis M, Arias A et al. Freethiamine is a potential biomarker of thiamine transporter-2 deficiency: a treatable cause of Leigh syndrome. Brain. 2016;139:31-38.

10. Said HM. Intestinal absorption of water-soluble vitamins in health and disease. Biochem J. 2011;437:357-372.

11. Subramanian VS, Subramanya SB, Said HM. Relative contribution of THTR-1 and THTR-2 in thiamin uptake by pancreatic acinar cells: studies utilizing Slc19a2 and Slc19a3 knockout mouse models. Am J Physiol Gastrointest Liver Physiol. 2012;302:572-578.

12. Subramanya SB, Subramanian VS, Sekar VT, Said HM. Thiamin uptake by pancreatic acinar cells: effect of chronic alcohol feeding/exposure. Am J Physiol Gastrointest Liver Physiol. 2011;301:896-904.

\section{SUMMARY}

The impact on large fibre function and small fibre function in patients with type 2 diabetes on benfotiamine therapy

\section{K. Singh, T. Yuzvenko}

Ukrainian Research and Practical Centre for Endocrine Surgery, Transplantation of Endocrine Organs and Tissues, Health Ministry of Ukraine, Kyiv

Diabetes mellitus (DM) is the leading cause of neuropathy worldwide. Based on the data from several studies, sensorimotor polyneuropathy (diffuse and symmetric neuropathy) will develop within 10 years of the onset of DM in $40 \%$ to $50 \%$ of patients with type 1 and type $2 \mathrm{DM}$. In patients with type $2 \mathrm{DM}$, target blood glucose levels are associated with a reduced incidence of neuropathy.

Objective - to study the correlation between the stage of diabetic peripheral polyneuropathy in type 2 diabetic patients, and the effects and efficacy of benfotiamine as transketolase activator.

Materials and methods. In this study, 190 patients with type 2 DM were screened for DPN. DPN was confirmed in 105 patients displaying both clinical manifestations of neuropathy with a positive Diabetic Neuropathy Symptom (DNS) score and increased vibration perception threshold (VPT) on a biotensiometer. Based on the above stated criteria patients were divided into 4 groups: 1 - with positive DNS score, positive $10 \mathrm{~g}$ monofilament test score, VPT between $16-25$ volts; 2 - with positive DNS score, positive $10 \mathrm{~g}$ monofilament test score, VPT between 26 - 35 volts; 3 - with positive DNS score, positive 10 $\mathrm{g}$ monofilament test score and VPT between 35-40 volts; 4 - control group with positive DNS score, negative $10 \mathrm{~g}$ monofilament test score and normal VPT value ( $n=25$ ( $23 \%) ; 20$ females and 5 males). The first 3 groups received benfotiamine $300 \mathrm{mg}$ daily for 6 weeks, the control group was benfothiamine naïve. All the groups continued their antidiabetic medication.

Results and discussion. The diabetic neuropathy score and vibration perception threshold was assessed in 105 patients ( 84 females and 21 males) with type 2 $\mathrm{DM}$, before starting of benfotiamine $300 \mathrm{mg}$ daily and after 6 weeks of therapy. Results of DNS: differences between group 3 and both group 1 and 2 were significant, but not between group 1 and 2. Patients in group $1(n=24)$, in females $(n=18)$ the DNS varied from $1-2$, and in males $(n=6)$ the DNS varied from $1-3$. After the 6 weeks,DNS score decreased in both females and males i.e. $1-1.25$ and $1-2.5$ correspondingly.

Conclusions. The role of benfotiamine in clinical practice has been demonstrated in many clinical trials with variable trial design, patient groups and history of diabetes. In our study we found that patients with mild neuropathy and vibration perception threshold of $16-25$ volts showed a reduction in VPT of up to $16 \%$, and the patients with moderate neuropathy and reduced vibration perception threshold of $26-35$ volts were the ones who benefitted the most from 
benfotiamine therapy. Benfotiamine activates transketolase and thus helps in the reduction of AGEs formation and associated sugar induced metabolic stress.

Key words: microvascular complications, transketolase, diabetic peripheral neuropathy, vibration perception threshold.

\section{PEЗЮME}

\section{Вплив терапії бенфотіаміном на функцію нервових волокон великого і малого діаметрів у хворих на цукровий діабет 2-го типу \\ К. Сінгх, Т. Ю. Юзвенко}

Український науково-практичний чентр ендокринної хірургії, трансплантації ендокринних органів і тканин мОЗ України, Київ

Цукровий діабет (ЦД) — основна причина нейропатії у всьому світі. На підставі даних декількох досліджень сенсомоторна полінейропатія (дифузна та симетрична нейропатія) розвивається упродовж 10 років від початку ЦД у 40-50 \% пацієнтів із ЦД 1-го та 2-го типів. У хворих на ЦД 2-го типу досягнення цільового рівня глюкози крові пов'язане зі зниженою частотою нейропатії.

Мета роботи - вивчити взаємозв'язок стадії діабетичної периферичної полінейропатії у хворих на ЦД 2-го типу, вплив та ефективність активаторів транскетолази як нового лікарського препарату.

Матеріали та методи. Обстежено 190 пацієнтів із ЦД 2-го типу та діабетичною полінейропатією (ДПН). ДПН було підтверджено у 105 пацієнтів шляхом виявлення клінічних проявів нейропатії з позитивним показником шкали діабетичної нейропатії (DNS) та підвищеним порогом сприйняття вібрації (VPT) на біотензіометрі. На підставі цих критеріїв пацієнтів розділили на 4 групи: 1-шу - з позитивними результатами DNS, позитивними результатами 10 г монофіламентного тесту та VPT між 16-25 B; 2-гу з позитивними результатами DNS, позитивними результатами 10 г монофіламентного тесту та VPT між 26-35 В; 3-тю - з позитивними результатами DNS, позитивними результатами 10 г монофіламентного тесту та VPT між 35-40 B; 4-ту (контрольну) з позитивними результатами шкали DNS, негативними результатами 10 г монофіламентного тесту та нормальним значенням VPT. Перші 3 групи отримували бенфотіамін по 300 мг щодня протягом 6 тиж. Пацієнти усіх груп продовжували приймати антидіабетичні препарати.
Результати та обговорення. ДПН та поріг вібраційного сприйняття оцінювали у 105 пацієнтів (84 жінки та 21 чоловік) із ЦД 2-го типу до початку прийому бенфотіаміну 300 мг щодня та після 6 тиж терапії. Результати DNS: відмінності між 3-ю та 1-ю і 2-ю групами були достовірними, чого не спостерігали між 1-ю і 2-ю групами. 324 пацієнтів 1-ї групи у 18 жінок DNS становив від 1-2, а у 6 чоловіків від 1 до 3. Через 6 тиж DNS знизився як у жінок, так і у чоловіків і становив $1-1,25$ та $1-2,5$ відповідно.

Висновки. У пацієнтів із легкою нейропатією та порогом вібраційного сприйняття 16-25 B VPT був знижений до $16 \%$, а найбільший ефект від використання бенфотіаміну спостерігали у пацієнтів із помірною нейропатією та зниженим порогом сприйняття вібрації (26-35 В). Бенфотіамін активує транскетолазу і завдяки цьому допомагає зменшити вираженість метаболічного стресу.

Ключові слова: мікросудинні ускладнення, транскетолаза, діабетична периферична нейропатія, поріг вібраційного сприйняття.

\section{PEЗЮME}

Влияние терапии бенфотиамином на фунцию нервных волокон большого и малого диаметров у больных сахарным диабетом 2-го типа

\section{К. Сингх, Т. Ю. Юзвенко}

Украинский научно-практический чентр эндокринной хирургии, трансплантации эндокринных органов и тканей МЗ Украины, Киев

Сахарный диабет (СД) - основная причина нейропатии во всем мире. На основании данных нескольких исследований сенсомоторная полинейропатия (диффузная и симметричная нейропатия) развивается в течение 10 лет с начала СД у $40-50 \%$ пациентов с СД 1-го и 2-го типов. У больных с СД 2-го типа достижение целевого уровня глюкозы крови связано со сниженной частотой нейропатии.

Цель работы - изучить взаимосвязь стадии диабетической периферической полинейропатии у больныхСД2-готипа свлиянием и эффективностью активаторов транскетолазы как нового лекарственного препарата.

Материалы и методы. Обследованы 190 пациентов с СД 2-го типа и диабетической полинейропатией (ДПН). ДПН была подтверждена у 105 пациентов путем выявления клинических проявлений нейропатии с положительным показателем шкалы диабетической нейропатии (DNS) и повышенным порогом 
восприятия вибрации (VPT) на биотензиометре. На основании этих критериев пациентов разделили на 4 группы: 1-ю - с положительными результатами DNS, положительными результатами 10 г монофиламентного теста и VPT между 16-25 B; 2-ю - с положительными результатами DNS, положительными результатами 10 г монофиламентного теста и VPT между 26-35 В; 3-ю - с положительными результатами DNS, положительными результатами 10 г монофиламентного теста и VPT между 35-40 B; 4-ю (контрольную) - сположительными результатами шкалы DNS, отрицательными результатами 10 г монофиламентного теста и нормальным значением VPT. Первые 3 группы получали бенфотиамин по 300 мг ежедневно в течение 6 нед. Пациенты всех групп продолжали принимать противодиабетические препараты.

Результаты и обсуждение. ДПН и порог вибрационного восприятия оценивали у 105 пациентов (84 женщины и 21 мужчина) с СД 2-го типа до начала приема бенфотиамина в дозе 300 мг ежедневно и после 6 нед терапии. Результаты DNS: различия между 3-й и 1-й и 2-й группами были достоверными, чего не наблюдалось между 1-й и 2-й группами. Из 24 пациентов 1-й группы у 18 женщин DNS составлял от $1-2$, а у 6 мужчин - от 1 до 3. Через 6 нед DNS снизился как у женщин, так и у мужчин и составил 1-1,25 и 1-2,5 соответственно.

Выводы. У пациентов с легкой нейропатией и порогом вибрационного восприятия 16-25 B VPT был снижен до $16 \%$, а наибольший эффект от использования бенфотиамина отмечен у пациентов с умеренной нейропатией и пониженным порогом восприятия вибрации (26-35 В). Бенфотиамин активирует транскетолазу и благодаря этому уменьшает выраженность метаболического стресса.

Ключевые слова: микрососудистые осложнения, транскетолаза, диабетическая периферическая нейропатия, порог вибрационного восприятия.

Дата надходження до редакиії 21.02.2020 p. 